\title{
Some altered concentrations of elements in semen of workers exposed to trinitrotoluene
}

\author{
H X Liu, W H Qin, G R Wang, Z Z Yang, Y X Chang, Q G Jiang
}

\begin{abstract}
Objectives-A cross sectional study was performed to find the concentrations of elements contained in the semen of workers exposed to trinitrotoluene (TNT).

Subjects and methods-Semen of exposed workers in two TNT plants located in He-Nan Province in 1992 were examined. Results-The average TNT concentrations in the workplace, except the packing site, were found to have exceeded the maximal allowable concentration (MAC, 1 $\mathbf{m g} / \mathbf{m}^{3}$ ); skin contaminations of male workers exposed to TNT were higher after a shift than in controls, and correlated with the total blood concentrations of TNT, 4-amino-2, 6-dinitrotoluene (4A), and 2-amino-4, 6-dinitrotoluene (2A). $\mathrm{Cu}, \mathrm{Zn}, \mathrm{Na}, \mathrm{Mg}$, and $\mathrm{Se}$ concentrations were significantly decreased, but $\mathrm{K}, \mathrm{Ca}$, Co, Mn and Li contents were not significantly changed in the semen of workers exposed to TNT. Compared with the control group, the percentage of liquifying time of semen, the sperm malformation incidence, and viability in the men exposed to TNT were all significantly changed.

Conclusions-Men exposed to TNT have decreased concentrations of some elements is semen and altered semen physiology.
\end{abstract}

(Occup Environ Med 1995;52:842-845)

Keywords: trinitrotoluene; semen; elements contained in semen

In recent years, we have found that the testis is one of the target organs affected by toxicity induced by trinitrotoluene (TNT). The TNT was actively reduced in the rat testicular microsome system in vitro. ${ }^{1}$ Rat testicular $\mathrm{Cu}$ and $\mathrm{Zn}$ concentrations were significantly reduced, but serum $\mathrm{Zn}$ concentration was significantly increased, whereas serum caeruloplasmin activity was decreased after six weeks of exposure to TNT. ${ }^{2}$ After TNT (50 200 $\mathrm{mg} / \mathrm{kg}$ ) was given orally for six weeks all experimental groups showed an increased proportion of morphologically abnormal sperm. ${ }^{3}$ Rat testicular enzyme activities were also disturbed: the activities of glucose-6-phosphate dehydrogenase, acid phosphatase, and lactate dehydrogenase were decreased after eight weeks exposure in two experimental groups (50 and $200 \mathrm{mg}$ TNT/kg body weight), whereas sorbitol dehydrogenase and non-specific esterase activities had decreased after six weeks of exposure in these same two groups. ${ }^{4}$ Rat testicular non-specific esterase activity increased after six and eight weeks exposure but only in the $200 \mathrm{mg} \mathrm{TNT} / \mathrm{kg}$ group. This enzyme activity in rat serum from the $200 \mathrm{mg}$ $\mathrm{TNT} / \mathrm{kg}$ group was also increased after six weeks exposure, but after eight weeks exposure it was increased in all dose groups (50, 100 , and $200 \mathrm{mg} T \mathrm{TNT} / \mathrm{kg}) .^{5}$ Rat testicular $\delta$-aminolaevulinic acid dehydratase activity did not significantly change in rat testicular homogenate but it was significantly increased in rat serum after $100 \mathrm{mg} \mathrm{TNT} / \mathrm{kg}$ were given orally for four weeks. The mean (SD) concentrations of superoxide radical, $\mathrm{H}_{2} \mathrm{O}_{2}$, and the product of lipid peroxide in Leydig cells incu-

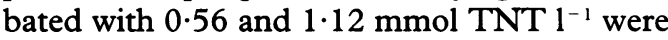
$0.140(0.011)$ and $0.198(0.020), 14.9(1.4)$ and $17.4(1.0)$, and $2.82(0.13)$ and 3.73 $(0.17) v$ controls $0.062(0.008) \mathrm{nmol} \mathrm{l}^{-1}, 13.8$ $(1.2) \mathrm{nmol}$, and $1.31(0.05) \mathrm{nmol}$, respectively. These exposed values were higher than those of the controls. These end points did not significantly change in Sertoli cells incubated with TNT. ${ }^{6}$ Testicular $\mathrm{Zn}$ in rats in the (TNT $+\mathrm{Zn}$ ) group (193 (115) $\mu \mathrm{g} / \mathrm{g}$ testis weight) was significantly higher than in the TNT group (179 (14) $\mu \mathrm{g} / \mathrm{g}$ testis weight), but was not significantly different from the control and the $\mathrm{Zn}$ groups. Rat testicular sorbitol dehydrogenase activity and serum testosterone concentration in the $(\mathrm{TNT}+\mathrm{Zn})$ group were not significantly different from those in the control, $\mathrm{Zn}$, and TNT groups. Therefore $\mathrm{Zn}$ had, at least partly, an antagonistic effect on male reproductive toxicity induced by $\mathrm{TNT}^{7}{ }^{7}$

In a pilot study more sexual disorderssuch as, impotence, loss of libido, and sexual hypoaesthesia-were found in male workers exposed to TNT $(63.5 \%)$ than in the control group $(5.4 \%)$; compared with the control group, the volume of semen and percentage of motile spermatozoa were significantly decreased, and the incidence of sperm malformation significantly increased in the exposed workers. Mean (SD) serum testosterone concentration $(480.0(120.0))$ in men exposed to TNT was significantly lower than in the control group $(585.0(95 \cdot 0) \mathrm{ng} / 100 \mathrm{ml}) .^{8}$

The present study was designed to seek further support for male reproductive toxicity induced by TNT. This was a cross sectional study performed in two civil explosive manufacturing plants located in He-Nan Province in 1991 to ascertain the reproductive and sexual functions of male workers exposed to 
TNT. It included a questionnaire survey of reproductive history and symptoms, a work history, an industrial hygiene investigation, a routine semen analysis, and measurement of the concentrations of 10 elements in semen.

\section{Materials and methods}

PRODUCTION PROCESS AND POPULATION STUDY The production process was the same in these two plants and was similar to that described previously. ${ }^{9}$ There are five jobs in the explosives production area: ball milling, mixing, cooling and drying, loading, and packing, but workers engaged in these five jobs often changed their work with each other.

Unexposed workers had no known exposure to chemicals and lived in the same city as the workers exposed to TNT. Table 1 shows the characteristics of semen contributors, both exposed to TNT and unexposed.

\section{HEALTH QUESTIONNAIRE}

The same health questionnaire and definition of sexual dysfunction were used as in previous work. ${ }^{9}$

\section{AIR, SKIN, AND BIOLOGICAL MONITORING}

Area air samples were taken by industrial hygienists in these two factories twice every year. The TNT in air was sampled on a commercial pervinyl chloride filter membrane at a flow rate of $20 \mathrm{l} / \mathrm{min}$. The sampling volume was 401 of air. A $95 \%$ ethanol solution $(10 \mathrm{ml})$ was used to dissolve the TNT. After adding $2.5 \% \mathrm{NaOH}(0.1 \mathrm{ml})$ to $5.0 \mathrm{ml}$ of this $95 \%$ ethanol solution, a colorimetric estimation was carried out. ${ }^{10}$

Samples from skin were collected after the shift to assess TNT contamination during two to four successive days: the skin $\left(2.5 \times 4 \mathrm{~cm}^{2}\right)$ of the back of the hand, neck, and chest was wiped with ethane on cotton balls, $10 \mathrm{ml}$ of $95 \%$ ethanol solution was then used to dissolve the TNT from the balls. Colorimetric analysis was then performed as already mentioned.

Table 1 Characteristics of semen contributors exposed and unexposed to TNT

\begin{tabular}{llllll}
\hline Groups & $\begin{array}{l}\text { Semen } \\
\text { samples }(n)\end{array}$ & $\begin{array}{l}\text { Mean }(S D) \\
\text { age }(y)\end{array}$ & $\begin{array}{l}\text { Mean }(S D) \\
\text { duration of exposure } \\
\text { or length } \\
\text { of service }(y)\end{array}$ & $\begin{array}{l}\text { Smoking } \\
(\%)\end{array}$ & $\begin{array}{l}\text { Drinking } \\
(\%)\end{array}$ \\
\hline Control A & 35 & $28 \cdot 5(8 \cdot 1)$ & $5 \cdot 7(2 \cdot 9)$ & $60 \cdot 4$ & $37 \cdot 3$ \\
Plant A & 35 & $21 \cdot 1(8 \cdot 5)$ & $4 \cdot 3(2 \cdot 2)$ & $65 \cdot 4$ & $39 \cdot 5$ \\
Control B & 43 & $30 \cdot 8(8 \cdot 9)$ & $10 \cdot 3(6 \cdot 9)$ & $64 \cdot 3$ & $40 \cdot 1$ \\
Plant B & 50 & $35 \cdot 0(9 \cdot 5)$ & $12 \cdot 5(7 \cdot 4)$ & $69 \cdot 4$ & $36 \cdot 1$ \\
\hline
\end{tabular}

Table 2 The TNT Air Concentrations ( $\left.\mathrm{mg} / \mathrm{m}^{3}\right)$ during 1992 in plants $A$ and B

\begin{tabular}{|c|c|c|c|}
\hline & & $M A C$ exceeded & Concentration $\left(\mathrm{mg} / \mathrm{m}^{3}\right)$ \\
\hline Fob & $n$ & $n(\%)$ & Geometric mean (range) \\
\hline $\begin{array}{l}\text { Plant A: } \\
\text { Ball milling } \\
\text { Mixing } \\
\text { Cooling and drying } \\
\text { Loading } \\
\text { Packing }\end{array}$ & $\begin{array}{l}17 \\
18 \\
18 \\
17 \\
17\end{array}$ & $\begin{array}{r}11(65) \\
4(22) \\
14(78) \\
14(82) \\
1(6)\end{array}$ & $\begin{array}{l}4.27(0.06-42 \cdot 8) \\
0.44(0.02-5 \cdot 70) \\
2.51(0.29-23 \cdot 7) \\
1.56(0.31-8.80) \\
0.41(0.06-2.03)\end{array}$ \\
\hline $\begin{array}{l}\text { Plant B: } \\
\text { Ball milling } \\
\text { Mixing } \\
\text { Cooling and drying } \\
\text { Loading } \\
\text { Packing }\end{array}$ & $\begin{array}{r}22 \\
19 \\
9 \\
18 \\
18\end{array}$ & $\begin{array}{c}13(59) \\
13(68) \\
6(67) \\
8(44) \\
1(6)\end{array}$ & $\begin{array}{l}1.13(0.17-26 \cdot 0) \\
1.36(0 \cdot 15-13 \cdot 6) \\
1.32(0.30-5.06) \\
1.01(0 \cdot 19-3.96) \\
0.35(0.12-4.94)\end{array}$ \\
\hline
\end{tabular}

Venous blood samples from each of the exposed and unexposed workers were analysed for TNT and its metabolites 4-amino-2, 5dinitrotoluene (4A) and 2-amino-4, 6-dinitrotoluene $(2 \mathrm{~A})$ by the high performance liquid chromatography (HPLC) method of Lui et al. ${ }^{11}$ To a $0.5 \mathrm{ml}$ blood sample $1.0 \mathrm{ml}$ of $\mathrm{H}_{2} \mathrm{O}$ was added, and after adding $0.15 \mathrm{ml}$ of concentrated $\mathrm{HCl}$, the blood sample was put into boiling water for 45 minutes. After cooling and neutralisation to $\mathrm{pH} 8 \cdot 0$, the blood sample was extracted twice with ether. The ether extract was evaporated to dryness in a $40^{\circ} \mathrm{C}$ water bath. To dissolve the TNT, $4 \mathrm{~A}$, and $2 \mathrm{~A} 0.25 \mathrm{ml}$ of methanol was added to the evaporating dish. For final measurement $0.25 \mathrm{ml}$ of $\mathrm{H}_{2} \mathrm{O}$ was added to the sample. Warian-Sy-5060 HPLC equipped with a UV detector was used with a $300 \times 4 \mathrm{~mm}$ reversed phase $\mathrm{C}_{-18}$ microbore column. The mobile phase was methanol: water (50:50) at a flow rate of $1.0 \mathrm{ml} / \mathrm{min}$. Column temperature was $30^{\circ} \mathrm{C}$ and $\mathrm{UV}$ wavelength was $235 \mathrm{~nm}$. Detection limits of TNT, $4 \mathrm{~A}$, and $2 \mathrm{~A}$ were $0.014,0.017$, and $0.018 \mu \mathrm{g} / \mathrm{ml}$ respectively. Average recovery rates of these three chemicals were $82 \cdot 8 \%, 88.6 \%$, and $93.9 \%$, respectively, at both 0.5 and $1 \mu \mathrm{g} / \mathrm{ml}$.

\section{SOME ELEMENTS IN SEMEN, AND SEMEN} ANALYSIS

Subjects were each required to produce a semen specimen at the clinic by masturbating into a clean jar, and the semen samples thus collected were analysed at once. These subjects were asked to abstain from sexual activities for a minimum of three days before the collection of their samples. The concentration of Se in semen was analysed by fluorospectrophotometry, ${ }^{12}$ concentrations of $\mathrm{Zn}$ and $\mathrm{Cu}$ in semen were measured as previously described. ${ }^{2}$ Other elements were measured by flame or graphite stove atomic absorption spectrophotometry. ${ }^{12}$ Sperm counts, volume and viability measurements, and morphologi$\mathrm{cal}$ analysis of semen slides were conducted by the methods described previously. ${ }^{9}$

\section{STATISTICAL METHODS}

Percentages of sexual dysfunction (table 5) and abnormal semen analysis (table 6) were compared by Fisher's test. Other data were analysed with two tailed Student's $t$ test. Correlation coefficients of the data were found with a routine formula. ${ }^{13}$

\section{Results}

The atmospheric monitoring in plants $A$ and $B$ showed that of the 173 air samples collected in 1992 in both plants, $51 \%$ of the samples from plant $A$ and $48 \%$ of the samples from plant B exceeded the maximal allowable concentration (MAC, $1 \mathrm{mg} / \mathrm{m}^{3}$ ) in China (table 2).

Skin concentrations of TNT in male exposed workers were higher at the end of the shift in plant $\mathrm{A}$ than in plant $\mathrm{B}$. The geometric mean of TNT concentrations from hand, neck, and chest in workers from plant $A$ were $36 \cdot 12,11.28$, and $7.97 \mu \mathrm{g} / \mathrm{cm}^{2}$, respectively (table 3). 
Table 3 Skin contaminations with TNT at the end of the shift $\left(\mu \mathrm{g} / \mathrm{cm}^{2}\right)$ in workers from plants $A$ and $B$ in 1992

\begin{tabular}{|c|c|c|c|c|}
\hline \multirow[b]{2}{*}{$f_{o b}$} & \multirow[b]{2}{*}{$\begin{array}{l}\text { Samples } \\
n\end{array}$} & \multirow{2}{*}{$\begin{array}{l}\text { Back of hand } \\
\text { Geometric } \\
\text { mean (range) }\end{array}$} & \multirow{2}{*}{$\begin{array}{l}\text { Neck } \\
\text { Geometric } \\
\text { mean (range) }\end{array}$} & \multirow{2}{*}{$\begin{array}{l}\text { Chest } \\
\text { Geometric } \\
\text { mean (range) }\end{array}$} \\
\hline & & & & \\
\hline $\begin{array}{l}\text { Plant A: } \\
\text { Ball milling } \\
\text { Mixing } \\
\text { Cooling and drying } \\
\text { Loading } \\
\text { Packing }\end{array}$ & $\begin{array}{l}4 \\
4 \\
2 \\
4 \\
4\end{array}$ & $\begin{array}{c}127(39 \cdot 2-200) \\
49 \cdot 6(20 \cdot 5-113) \\
8 \cdot 76(5 \cdot 33-12 \cdot 2) \\
47 \cdot 8(4 \cdot 42-51 \cdot 2) \\
25 \cdot 4(4 \cdot 00-50 \cdot 0)\end{array}$ & $\begin{array}{c}24 \cdot 1(5 \cdot 58-45 \cdot 0) \\
12 \cdot 4(5 \cdot 13-28 \cdot 3) \\
6 \cdot 76(6 \cdot 35-7 \cdot 17) \\
13 \cdot 9(8 \cdot 52-17 \cdot 5) \\
6 \cdot 49(5 \cdot 00-8 \cdot 52)\end{array}$ & $\begin{array}{c}16 \cdot 0(8 \cdot 67-33 \cdot 3) \\
5 \cdot 60(3 \cdot 00-10 \cdot 8) \\
9.32(5 \cdot 33-15 \cdot 3) \\
9 \cdot 20(3.92-20 \cdot 8) \\
4 \cdot 18(1.50-5 \cdot 56)\end{array}$ \\
\hline $\begin{array}{l}\text { Plant B: } \\
\text { Ball milling } \\
\text { Mixing } \\
\text { Cooling and drying } \\
\text { Loading } \\
\text { Packing }\end{array}$ & $\begin{array}{l}4 \\
4 \\
2 \\
4 \\
4\end{array}$ & $\begin{array}{c}3.24(1.52-6 \cdot 91) \\
6 \cdot 77(3 \cdot 39-12 \cdot 7) \\
79 \cdot 0(5 \cdot 33-153) \\
66 \cdot 8(2 \cdot 27-124) \\
47 \cdot 7(3 \cdot 82-156)\end{array}$ & $\begin{array}{c}6 \cdot 14(2 \cdot 48-11 \cdot 5) \\
3.84(1.18-5 \cdot 00) \\
10 \cdot 6(7 \cdot 17-14 \cdot 0) \\
24.9(12 \cdot 5-42.9) \\
3 \cdot 22(0 \cdot 15-8 \cdot 00)\end{array}$ & $\begin{array}{c}4.25(1.81-7 \cdot 71) \\
5.40(0.62-16.6) \\
8.48(3.35-13.6) \\
11.8(5.33-22.9) \\
3.64(0 \cdot 15-6.55)\end{array}$ \\
\hline
\end{tabular}

Table 4 Blood TNT and its two metabolites $(\mu \mathrm{g} / \mathrm{ml})$ in male workers exposed to TNT

\begin{tabular}{llllll}
\hline & \multicolumn{2}{l}{ Plant $A$} & & \multicolumn{2}{l}{ Plant $B$} \\
\cline { 2 - 3 } \cline { 5 - 5 } Chemicals & $n$ & $X(S D)$ & & $n$ & $X(S D)$ \\
\hline TNT & 34 & $0 \cdot 161(0.048)$ & & 59 & $0 \cdot 091(0.075)$ \\
4A & 34 & $0.404(0.218)$ & & 59 & $0 \cdot 286(0.132)$ \\
2A & 34 & $0.126(0.056)$ & & 59 & $0 \cdot 169(0.090)$ \\
\hline
\end{tabular}

Table 5 Sexual functions in male workers exposed to TNT from plants $A$ and $B$ and control workers

\begin{tabular}{llllll}
\hline & \multicolumn{4}{l}{ Sexual dysfunctions } \\
\cline { 3 - 6 } Groups & $n$ & $\begin{array}{l}\text { Loss of } \\
\text { libido }\end{array}$ & Prospermia & Impotence & Sum \\
\hline Control & 72 & 2 & 6 & 0 & $8(11 \cdot 1)$ \\
Exposed & 42 & 9 & 6 & 1 & $16(38 \cdot 1)^{\star \star}$ \\
\hline$\star \star \mathrm{P}<0.01$ & & & & &
\end{tabular}

Biological monitoring was similar to environmental monitoring. The blood concentrations of TNT, $4 \mathrm{~A}$, and $2 \mathrm{~A}$ combined in workers from plants $A$ and $B$ were 0.691 and $0.546 \mu \mathrm{g} / \mathrm{ml}$ respectively (table 4 ). The skin contamination of TNT after the shift in exposed male workers showed a significant correlation with the total blood concentration of TNT, 4A, and 2A:

$$
\begin{array}{ll}
Y=0.559+0.0127 X & \text { plant A } \\
Y=0.3516+0.02607 X & \text { plant B }
\end{array}
$$

where, $\mathrm{Y}$ is the total blood concentration of TNT, 4A, and $2 \mathrm{~A}$, and $\mathrm{X}$ is the skin TNT contamination at the end of the shift; $r=0.4502(\mathrm{P}<0.052)$ for plant $\mathrm{A}$ workers and $r=0.904(\mathrm{P}<0.001)$ for plant $\mathrm{B}$ workers.

More sexual disorders, such as impotence, loss of libido, and hypoaesthesia, were found in the male workers exposed to TNT than in the control group; impotence or prospermia did not occur in the same workers (table 5). Compared with the control group, the liquefying time of semen was extended, the percentage of motile spermatozoa was significantly decreased, and the incidence of sperm malformation was significantly increased in workers exposed to TNT (table 6).

Concentrations of $\mathrm{Cu}, \mathrm{Zn}, \mathrm{Na}$, and $\mathrm{Mg}$ in semen were significantly decreased in workers exposed to TNT from both plants A and B (table 7). Concentrations of $\mathrm{Se}$ in semen were significantly decreased in the plant $B$. Concentrations of $\mathrm{K}, \mathrm{Ca}, \mathrm{Mn}$, and $\mathrm{Li}$ in semen were not significantly different between the two groups (data not shown).

\section{Discussion}

Both the air TNT concentrations in these two plants and skin concentrations of TNT at the end of the shift in exposed workers proved that workers exposed to TNT in these two plants have had very serious exposure. The results of air TNT concentration (table 2), skin contamination with TNT at the end of the shift (table 3 ), and blood TNT, 4A, and $2 \mathrm{~A}$ concentrations (table 4) showed that the industrial conditions were more serious in plant $A$ than in plant $B$. The fact that the total blood concentrations of TNT, $4 \mathrm{~A}$, and $2 \mathrm{~A}$ were significantly related to skin contamination at the end of the shift supports the view that TNT is mainly absorbed through the skin. ${ }^{14}$ In measurements of blood TNT and its two metabolites, $4 \mathrm{~A}$ and $2 \mathrm{~A}$, the highest one was $4 \mathrm{~A}$. This metabolite also had the highest concentration when TNT and its major metabolites were measured in the urine samples of workers

\begin{tabular}{|c|c|c|c|c|c|c|c|c|}
\hline \multirow[b]{2}{*}{ Characteristics } & \multicolumn{2}{|c|}{ Control $(n=50)$} & \multicolumn{2}{|c|}{$\begin{array}{l}\text { Exposed } \\
\text { (plant } A, n=49)\end{array}$} & \multicolumn{2}{|c|}{ Control $(n=50)$} & \multicolumn{2}{|c|}{$\begin{array}{l}\text { Exposed } \\
\text { (Plant } B, n=48)\end{array}$} \\
\hline & $n$ & $\%$ & $n$ & $\%$ & $n$ & $\%$ & $n$ & $\%$ \\
\hline Volume (< $1.5 \mathrm{ml} /$ ejaculation $)$ & 9 & $18 \cdot 0$ & 10 & $20 \cdot 4$ & 10 & 20 & 11 & $22 \cdot 9$ \\
\hline Liquefying time $(>60 \mathrm{~min})$ & 2 & $4 \cdot 0$ & 10 & $20 \cdot 4^{\star \star}$ & 1 & 2 & 13 & $29 \cdot 1^{\star \star}$ \\
\hline Sperm concentration $\left(<6 \times 10^{7} \cdot \mathrm{ml}^{-1}\right)$ & 14 & $28 \cdot 0$ & 20 & $40 \cdot 1$ & 10 & 20 & 16 & $33 \cdot 3$ \\
\hline $\begin{array}{l}\text { Higher incidence of abnormal } \\
\text { morphology }(>25 \%)\end{array}$ & 0 & 0.0 & 11 & $22 \cdot 4^{\star \star}$ & 0 & 0 & 13 & $27 \cdot 1^{\star \star}$ \\
\hline Viability ( $<60 \%)$ & 6 & 12.0 & 22 & 44.9 ${ }^{\star \star}$ & 4 & 8 & 25 & $52 \cdot 0^{\star \star}$ \\
\hline
\end{tabular}

Table 6 Semen characteristics of workers exposed to TNT from plants $A$ and $B$ and control workers

Table 7 Concentrations of $\mathrm{Cu}, \mathrm{Zn}, \mathrm{Na}, \mathrm{Mg}$ and $\mathrm{Se}(\mu \mathrm{g} / \mathrm{ml})$ in semen from workers exposed to $T N T$ (mean (SD))

\begin{tabular}{lllllll}
\hline Groups & $n$ & $C u$ & $Z n$ & $N a$ & $M g$ & $S e$ \\
\hline Plant A & 35 & $0 \cdot 295(0 \cdot 103)^{\star}$ & $214(119)^{\star}$ & $2857(280)^{\star \star}$ & $125(76 \cdot 0)^{\star}$ & - \\
Control A & 35 & $0 \cdot 383(0 \cdot 232)$ & $262(116)$ & $3349(497)$ & $166(73 \cdot 8)$ & - \\
Plant B & 43 & $0 \cdot 555(0.432)^{\star \star}$ & $296(76 \cdot 6)^{\star \star}$ & $3248(755)^{\star \star}$ & $123(49 \cdot 7)^{\star \star}$ & $0.084(0 \cdot 036) \star \star$ \\
Control B & 50 & $0.856(0.455)$ & $385(175)$ & $3749(559)$ & $188(65 \cdot 3)$ & $0 \cdot 149(0 \cdot 054)$ \\
\hline
\end{tabular}

$\mathrm{P}<0.05 ;{ }^{\star \star} \mathrm{P}<0.01 ; v$ controls. 
exposed to TNT. ${ }^{15}$ Therefore, blood concentration of $4 \mathrm{~A}$ could also be used as an indicator in biological monitoring of workers exposed to TNT.

Compared with the control group, we confirm the previous results that male workers exposed to TNT show sexual dysfunction (impotence, loss of libido, and prospermia) and abnormal semen analysis (increased incidence of sperm malformation and liquefying time, decreased viability). ${ }^{8}$

Magnesium is one of the essential elements for the living body, as almost all fundamental cell reactions, such as protein biosynthesis and anaerobic energy production, require $\mathbf{M g}^{++}$ ions. Magnesium serves as an activator for many enzyme systems of metabolism within the cell. Most important among these enzymes are those that hydrolyse and transfer phosphate groups, including the enzymes concerned with reactions involving ATP. ${ }^{16}$ Therefore, lower $\mathrm{Mg}$ content in the semen of workers exposed to TNT may relate to the abnormal results of routine semen analysis on the workers exposed to TNT.

The semen $\mathrm{Zn}$ and $\mathrm{Cu}$ contents were very different (table 5) even in the two control groups located in two different cities. This may reflect the influence of different diets. Therefore, a local control group is needed for comparing the results of $\mathrm{Zn}$ and $\mathrm{Cu}$ metabolism in case these are influenced by chemical toxicity.

Zinc and $\mathrm{Cu}$ metabolism were disturbed in rats and workers exposed to TNT. Zinc concentrations in rat testes were significantly decreased, and in serum increased. Zinc concentrations in both hair and serum of male workers exposed to TNT were significantly increased. ${ }^{2}{ }^{17}$ Semen $\mathrm{Zn}$ concentrations in workers exposed to TNT were significantly decreased in this study. The $\mathrm{Cu}$ content of rat testes, and serum and hair of exposed workers were all significantly decreased. ${ }^{2}$ The $\mathrm{Cu}$ content of semen of exposed workers was also significantly decreased in this study. Therefore, $\mathrm{Zn}$ and $\mathrm{Cu}$ metabolism were disturbed by TNT toxicity.

The relation between hair, serum, blood, and semen concentrations of $\mathrm{Zn}$ and $\mathrm{Cu}$ in semen should be further studied. The mechanism of disturbed $\mathrm{Zn}$ and $\mathrm{Cu}$ metabolism induced by TNT toxicity has not yet been established. It was found that $\mathrm{Zn}$ and $\mathrm{Cu}$ metabolism were regulated by hormone concentrations. Serum testosterone, LH, and FSH concentrations were significantly changed by TNT toxicity. ${ }^{18}$ Therefore, disturbed sex hormone concentrations induced by TNT toxicity in both exposed male workers and rats may affect, at least in part, the $\mathrm{Zn}$ and $\mathrm{Cu}$ metabolism.

The toxicant TNT produces oxidative stress. ${ }^{19}$ Its toxicity was synergic if the animal's diet was deprived of Se or vitamin E. ${ }^{20}{ }^{21}$ It is not surprising to see that the Se content in workers exposed to TNT was far below that in control workers.

1 Kong LY, Jiang QG, Qu QS. Formation of superoxide radical and hydrogen peroxide enhanced by trinitrotoluene (TNT) in rat liver, brain, kidney, and testicle in vitro and monkey liver in vivo. Biomed Environ Sci 1989;2:272-7.

2 Jiang QG, Sun JG, Qin XF. The effects of TNT toxicity on zinc and copper metabolism. Toxicol Lett 1991;55:343-9.

3 Hen SR, Jiang QG. The effect of TNT on the rat sperm. Fournal of Health Toxicology 1993;15:233. (In Chinese.)

$4 \mathrm{Li}$ Y, Jiang QG. Effects of TNT on male reproductive functions. Fournal of Health Toxicology 1992;6:252-4. (In Chinese.)

5 Liu WY Chang YX, Jiang QG. Effects of TNT on activity of non-specific esterase and $\delta$-aminolevulinic acid dehydratase in blood and testis. Fournal of Health Toxicology 1993;7:200-1. (In Chinese.)

6 Cui JW, Zhao CY, Yie KP, Shi LP, Yin H, Chang YX, Jiang QG. Reductive activation of TNT and lipid peroxidation induced by it in leydig cells and Sertoli cells of rat testis. Chinese fournal of Pharmacology and Toxicology testis. Chinese Fournal of

7 Wu LB, Jiang QG, Chang YX. Zinc supplement antagonizes testicle damage induced by TNT. Fournal of Health Toxicology 1993;7:242-5. (In Chinese.)

$8 \mathrm{Li}$ Y, Jiang QG, Chang YX, Shen WG, Cui JW, Liu W, et al. Effects of exposure to TNT on male reproduction. Chinese fournal of Industrial Medicine 1993;6:69-71. (In Chinese.)

9 Li Y, Jiang QG, Yao SQ, Liu W, Tian GJ, Cui JW. Effects of exposure to TNT on male reproduction. Biomed Environ Sci 1993;6:154-60.

$10 \mathrm{Liu}$ RD. Analysis methods for the hazardous chemicals in air, 2nd edition. Beijing: People Health Publication, 1986: 483-4.

11 Liu HX, Wang GR, Li VS, Yang ZZ, Chang YX, Cui JW, et $a l$. Detection and analysis of TNT and its metabolites in blood of munition workers by HPLC. Chinese fournal of Industrial Hygiene and Occupational Diseases 1993;11: 226-7. (In Chinese.)

12 Versieck J, Cornelis R. Trace elements in human plasma and serum. Florida: CRC Press, 1989: 8-10.

13 Brown BW, Hollander M. Statistics: a biomedical introduction. New York: John Willey, 1977: 26-308, 90-1, 195-224.

14 Woollen BW, Hollander MG, Craig R, Steel GT. Assessment of occupational absorption during manufacAssessment of occupational absorption during man

15 Yinon J. Toxicity and metabolism of explosives. Florida: CRC Press, 1990: 28.

16 Aikawa JK. Magnesium: its biologic significance. Florida: CRC Press, 1981:27.

17 Chang YX, Wu LB, Cui JW, Zhao CY, Jiang QG, Liu HX, et al. Effects of TNT on the serum lipid peroxidate, copper and zinc contents of exposed workers. Chinese fournal of Industrial Hygiene and Occupational Diseases 1993;11: 362-3. (In Chinese.)

18 Wu LB , Jiang QG, Chang YX. Effect of TNT on serum testosterone, follicle-stimulating hormone, and luteinizing hormone levels on male workers. Fournal of Health ing hormone levels on male workers. Fournal

19 Jiang QG. The study of TNT toxicology. In: Jiang QG, Liu $\mathrm{ZS}$, eds. TNT poisoning and its prevention and treatment.
iang ZS, eds. TNT poisoning and its prevention and treat

20 Zhuang ZX, Liu SZ, Jiang QG. A study on the relationship between vitamin $E$ nutritional status and liver thiol and calcium homeostasis after TNT acute administration in rats. Chinese fournal of Industrial Hygiene and Occupational Diseases 1991;9:23-5 (In Chinese.)

21 Shen WG, Yuan S, Li JX. Effect of selenium deficiency on TNT toxicity. Fournal of Trace Elements 1990;12-4. (In Chinese.) 